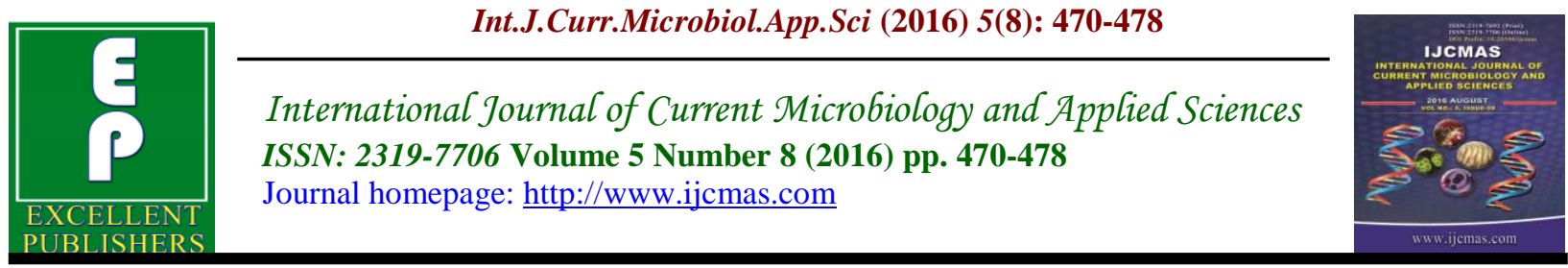

Original Research Article

http://dx.doi.org/10.20546/ijcmas.2016.508.050

\title{
The Role of Momordica charantia in Reducing the Level of Glucose in Mice
}

\author{
Maha Hameed A. Al-Bahrani* \\ Molecular and Medical Biotechnology Department, College of Applied \\ Biotechnology, Al-Nahrin University, Baghdad, Iraq \\ *Corresponding author
}

\begin{abstract}
A B S T R A C T
Keywords

Momordica

charantia,

Glucose in Mice,

Experimental

diabetes.

\section{Article Info}

Accepted:

21 July 2016

Available Online:

10 August 2016

The effects of aqueous and alcoholic extract (Momordica charantia) on the level of serum glucose were studied on 40 mature males distributed into 5 equal groups and fed basal diets. Group (1) was kept as control negative (fed on basal diet), while the other 4 groups were subcutaneously administered a single dosage of alloxan to induce experimental diabetes. Group (2) was left as a control positive group (diabetes) while the other groups (3), (4) and (5) were orally given Momordica charantia once a day at a dosage of $0.10,0.20$ and $0.40 \mathrm{mg} / \mathrm{ml}$ respectively, for 10 days. At the end of the experiment, blood samples from all mice were collected for a biochemical analysis. The results had an effect on the glucose level of the serum, at $0.30 \mathrm{mg} / \mathrm{ml}$ of water extract of Momordica charantia. On the other hand, there are no effects on the glucose level at the higher dosages of Methanolic Momordica charantia extract.
\end{abstract}

\section{Introduction}

Momordica charantia is a herbal plant that belongs to The family cucurbitaceous (Whitaker et al., 1990). It has been commonly consumed as a vegetable and used as a medicinal herb in India, China, Africa and in various parts of wounds, ulcer, eczema, jaundice, kidney stone, leprosy and scabies (Basch et al., 2003). The main constituents of Momordica charantia which are responsible for medicinal effects are triterpenes, steroids, alkaloids, in organics, lipids and phenolic compounds) Grover et al., 2004). Phenolic compounds are categorized as secondary metabolites essential for growth and reproduction of plants.
They are known as hydrophilic antioxidants, and are produced as a response for defending injured plants against pathogens. They potentially show antioxidant, anti mutagen, antitumor, anti-inflammatory and anti carcinogenic properties (Lee et al., 2003). Free radicals are known to be the major cause of various chronic and degenerative diseases, including aging, coronary heart disease, inflammation, diabetes mellitus and cancer (Cheng et al., 2003). Recently, natural foods and food derived antioxidants such as vitamins and phenol phytochemicals have received growing attention because they are known to function as chemo protective agents against the oxidative damage ( $\mathrm{Wu}$ et al., 2008). 
Natural products and many active principles identified from plant species are known to play an important role in pharmaceutical biology (Joseph and Jini, 2011). Momordica charantiahas a significant antidiabetic activity so that it can be used to treat diabetes as well as to delay the late complications of diabetes. In the present review, the possible antidiabetic activity of Momordica charantia has been elucidated in addition to and its medicinal potency responsible for the hypoglycemic activity.

The aim of the present study to elucidate the possible antidiabetic activity Momordica charantia extract in relieving symptoms and conditions of diabetes in experimental animals.

\section{What is Momordica charantia?}

Momordica charantia is a tall-growing annual fruit originated in South-East Asia. It can also be cultivated in Africa, South America, and India. The plant belongs to the Cucurbitaceae family in the Momordica genus of climbing vines and it is considered a member of the same family as squash, watermelon, cantaloupes, cucumber, etc (Kar et al., 2003). Momordica charantiaare characterized by lobed leaves, yellow flowers, and edible fruit pod with bittertaste. The fruit color is green with cucumber-shaped (as shown in figure 1.1), soft lengthwise ridges and surface bumps. As the fruit begin to mature gradually it become hard, turn yellow or brown in color. All parts of Momordica charantia (fruit, leaves, seeds, seed oil, and roots) are used (Der-Marderosian and Beutler, 2010). The genus Momordica contains about 60 species from the old world tropics (Stevens, 2012). The generic name apparently derives from the Latin mordeo (to bite), perhaps a reference to the jagged edges of the seeds; charantia is from the ancient Greek for beautiful flower.The species Momordica balsamina has edible fruit, and is widely distributed as crops becoming naturalized throughout the tropics. The scientific name of this fruit isMomordica charantia L. Momordica charantia has also different common names including Momordica charantia, Bitter gourd, Karilla fruit, Balsam pear, Karolla, Cearasee and carillac undeamor. Momordica charantia in some English texts may be called by its local names. In Arabic, it is knowns as KhyarKarillash, in South Asia, as karela, in Kannada, paavayka, in Bengali, kerela, in Island Southeast Asia, ampalaya, in Filipino, parya,and peria in Malaysian, and pare in Javanese and Indonesian (Englberger, 2009; I3N-Brazil, 2014). In East Asia, it is known as kugua,in Chinese, yeoju in Korean, caraille or carilley in Latin America, Panama and some parts of central America it is known as balsamino, cerasee or sorosi in Jamaica and in some regions of South America and elsewhere, it is known as kudhrethnarhyas in Turkey (Lim, 2013).

\section{Bio-active compounds of Momordica charantia in relation to its physiological functions}

Previous studies have shown that water extracts of the leaf and fruit of Momordica charantia have a strong antioxidant activity and that Momordica charantia fractions are rich in phenolics (Kubola and Siriamornpun, 2008). The fruit of Momordica charantia have been reported to have significant compounds such as saponins (Matsuda et al., 1998) and peptides (Yuan et al., 2008); cucurbitane-type triterpenoid that is like the Charantin, an antidiabetic substance promising for the treatment of diabetes (Lee et al., 2009). Many extracts studies of Momordica charantia have been investigated to possess antitumor activity, through the inhibition of mouse spontaneous 
mammary tumourigenesis (Nagasawa et al., 2002). Besides, anti-tumor activities, the antiviral (Lee et al., 1995), and immunomodulating properties (Cunnick et al., 1990) of this plant have also been reported. Recently, More than 50 triterpenoids have been isolated from Momordica charantia with different biological activities, some triterpenoids have antiproliferative and anti-invasive activities (Chen et al., 2009). Moreover, two types of Flavonoids such as (rutin, naringin) extracted from the leaves of Momordica charantia successfully show growth inhibition of leukemia and ovarian carcinomas, with anti-invasive effects on melanoma.Such flavoniods might be promising components with critical roles against cancer cell progression (Yasuda et al., 2009).The phenolic acids such asgentistic acid, benzoic acid, ocoumaric acid, and $t$-cinnamic acid, from Momordica charantiaare reported to exhibit an antioxidant activity (Horax et al., 2005).

\section{Anti-diabetic effect of Momordica charantia}

There are many old herbal remedies that have been used to relieve symptoms or treat diabetes in many developing countries (Singh, 2011). Momordica charantia is one of most important plants that have been traditionally used for the treatment of diabetes (Hasan andKhatoon, 2012). Many studies have shown anti-hyperglycemic and hypoglycemic effects of the different extracts of Momordica charantia in both human and experimental animals (Fuangchana et al., 2011; Wehash et al., 2012).

Various extracts and components of Momordica charantia are attributed to the increasing glucose utilization in the liver through different physiological, pharmacological and biochemical modes (Bhushan et al., 2010). The hypoglycemic actions of Momordica charantia have many modes including the hypoglycemic effect (Ragasa et al., 2011),stimulating insulin release from isolated beta cells(Ahmed et al., 1998)stimulating utilization of peripheral and skeletal muscle glucose (Akhtar et al., 2011),inhibiting theglucose uptake of intestinal (Abdollah et al.,2010), inhibitingthe differentiation of adipocyte (Nerurkar et al.,2010), suppressing many gluconeogenic enzymes (Singh et al.,2011), stimulating the key enzyme of HMP pathway (Shibib et al.,1993) and inducing glucose uptake in liver (Welihinda et al.,1986).

\section{Methods}

This research was conducted in the period from January 2016 until March 2016. Animal maintenance was performed at the Animal Hospital of Biotechnology Research Center at Al-Nahrin University, while the sample testing was carried out in the Laboratory of Enzymology Medical Department at Applied Biotechnology College.

\section{Plant collection}

The plant (Momordica charantia) was bought from the Malaysian market by Dr. Raghda Saad, Molecular and Medical Biotechnology Department, of Applied Biotechnology College/ AL-Nahrain University. The plant fruit were air dried at room temperature and crashed to be extracted.

\section{Plant extraction}

The manufacture of aqueous extract of Momordica charantia dry fruit were milled to obtain dry powder. Dry powder of 
Momordica charantia fruit as much as $15 \mathrm{~g}$, half amount was then extracted with $1 \mathrm{~L}$ of water $(1: 5)$ for 2 hours at $100^{\circ} \mathrm{C}$ as reflux, then filtered with filter paper. The extract was dried using a rotary evaporator with a temperature of $50{ }^{\circ} \mathrm{C}$ to obtain crude extract of Momordica charantia fruit. The other half amount was extracted with $70 \%$ methanol (1:5) according to Fua et al. (2010) by using shaker incubator 25 c for 24hr. Buchner funnel was used to filter the extracted solution. Then, the rotary evaporator was used at $40^{\circ} \mathrm{C}$ to concentrate the filtered solution, finally the filtered solution was evaporated by lyophilize, and the resultant crude powder was kept at -20 ${ }^{\circ} \mathrm{C}$ until use.

\section{Experimental design}

Animals male mice with an age of 6 weeks were divided into five groups (5 each): control positive, Momordica charantia dose $10 \mathrm{mg} / \mathrm{ml}$, and Momordica charantia dose $20 \mathrm{mg} / \mathrm{ml}$ and Momordica charantia dose 40 $\mathrm{mg} / \mathrm{ml}$. Mice in the control negative only fed the standard until the end of the treatment, while the remaining (20 rats) were fed basal dietand injected with $100 \mu \mathrm{l}$ of aloxan $/ \mathrm{kg}$ of body weight three times during the same week then the glucose level were examined after one week.

The period of treatment was restricted for 10 days. The water and alcoholic extract of Momordica charantia were injected subcutaneously $(100 \mu \mathrm{l})$ every day for 10 days. At the end of treatment, blood samples were collected $(600-1000 \mu \mathrm{l})$.

The measurement the glucose level was done by using the glucose kit from bio System Company. The color that appeared was measured by a spectrophotometer and the absorbance was read at the wavelength $500 \mathrm{~nm}$.

\section{Determination of glucose oxidase (GOD) activity}

A colorimetric method using 4aminoantipyrine- in a glucose oxidaseperoxidase system was proposed to determine the glucose level in the biological system. The principle involved in the estimation of glucose level was firstly the $\beta$ $\mathrm{D}$ glucose to be oxidized into gluconic acid and hydrogen peroxide in the presence of glucose oxidase (GOD). The hydrogen peroxides the reacts with phenol and 4amino antipyrine by the action of peroxidase to form a pink colored quinoamine dye complex. In the present work, the level of $\beta$ $D$ glucose was measured before and after the exposure of the glucose oxidase to radiation, the absorbance of the samples and standards was read against the blank at $500 \mathrm{~nm}$. All the working steps were done doe according to the procedure of Sigma Company.

\section{Sample preparation}

Reagent 1 includes:

A: (Buffer solution): $50 \mathrm{mM}$ sodium acetate buffer, then adjust to $\mathrm{pH} 5.1$ at $35^{\circ} \mathrm{C}$ with 1 $\mathrm{M} \mathrm{HCl}$.)

B: $O$-Dianisidine Dihydrochloride (ODD): This reagent was prepared immediately by dissolving $10 \mathrm{mg}$ in $4 \mathrm{ml}$ of distilled water to obtain $0.21 \mathrm{mMof}$ final concentration.

C: Peroxidase enzyme solution (POD)

D: Glucose Oxidase enzyme solution (GOD): This solution was prepared immediately before use.It contains 0.2 $\mathrm{mg} / \mathrm{ml}$ of Glucose oxidase.

Reagent 2 (Standard solution): glucose solution $\quad(10 \% \quad(\mathrm{w} / \mathrm{v}) . \quad$ standard solution.pipette the following reagents into a test tube as follow: 


\begin{tabular}{|c|c|c|c|c|}
\hline Reagent/serum & $\begin{array}{l}\begin{array}{l}\text { Volume } \\
(\mu \mathrm{l}) \text { Test }\end{array} \\
\end{array}$ & $\begin{array}{cc}\text { Volume }(\mu \mathrm{l}) \\
\text { blank }\end{array}$ & Volume & $\begin{array}{c}\mu \mathrm{l}) \\
\text { Standard }\end{array}$ \\
\hline Serum & 10 & ------ & & ------ \\
\hline Reagent 1 & 1000 & 1000 & & 1000 \\
\hline Reagent 2 & ---- & ----- & & 10 \\
\hline
\end{tabular}

Table.1 Comparision between methanol extract and water extractofMomordica charantia

\begin{tabular}{|c|c|c|c|}
\hline \multirow{2}{*}{ Treatment (Dosage) } & \multicolumn{2}{|c|}{ Mean \pm SD } & \multirow{2}{*}{ LSD value } \\
\cline { 2 - 3 } & Methanol extract & Water extract & \\
\hline \hline $0.075(\mathrm{mg} / \mathrm{ml})$ & $273.00 \pm 83.16$ & $260.67 \pm 28.08$ & $28.913 \mathrm{NS}$ \\
\hline \hline $0.15(\mathrm{mg} / \mathrm{ml})$ & $266.00 \pm 65.73$ & $173.67 \pm 12.23$ & $33.612 *$ \\
\hline $0.30(\mathrm{mg} / \mathrm{ml})$ & $247.67 \pm 25.46$ & $155.00 \pm 7.81$ & $27.053 *$ \\
\hline & $*(\mathrm{P}<0.05)$, NS: Non-significant. \\
\hline
\end{tabular}

All samples were mixed, then incubated for $5 \mathrm{mn}$ at $37^{\circ} \mathrm{C}$. The increase in $\mathrm{A}_{500 \mathrm{~nm}}$ was recorded and the A500/time (minute) was obtained by using the maximum linear rate for both tests $\Delta 7.5$ unit $/ \mathrm{ml}=\Delta \mathrm{A} 500 \mathrm{~mm}$. The colour was stable for $30 \mathrm{mn}$. Then, the results were recorded immediately (Bergmeyer et al., 1974).

Equation: absorbance of test/ absorbance of stander X 100

\section{Statistical Analysis}

The Statistical Analysis System- SAS (2012) program was used to affect the difference factors in the study parameters. The least significant difference -LSD test was used to significantly compare between the means in this study.

\section{Result and Discussion}

The main target of the present study was to test the Momordica charantia in reducing the glucose level in mice suffering from type 2 diabetes after treatment with $100 \mu$ of water and alcoholic extract of Momordica charantia for 10 days at different dosages of both extracts.

\section{Yield of Crude Extracts}

One species of Momordica charantia was extracted using two solvents systems namely, 70\% methanol and water and the results were illustrated as bellow:

Various studies assessed the effects of Momordica charantia on blood glucoselevel in healthy and diabetics individuals. The results found no significant changes in random blood glucose concentration following treatment with alcoholic extraction at different dosages in comparison to the water extraction of plants. The significant reduction was seen in the level of glucose in the serum of mice after treatment with 100 and $150 \mathrm{mg} / \mathrm{ml}$ of Momordica charantia in comparison to the a standard control group. A similar study by Lim et al.,(2010) showed that the Momordica charantia ingested the capsule of either fruit or leaves did not significantly reduce the blood glucose levels compared to when it was consumed orally, or injected subcutaneously under skin or in juice form. A study by Dans et al., (2007) has shown no significant effect on fasting blood glucose from capsules of Momordica charantia isolated from Philippines. Therefore, further 
studies are required to determine the efficacy of different species of Momordica charantia inmodulating the level of glucose in serum in humans, particularly in a raw or fresh form together with rice-based meals, as commonly consumed in Malaysia (Mohd et al., 2014).

Many animal studies have shown hypoglycaemic effects of different parts of Momordica charantia in normal animals (Mohammady et al., 2012). Another animal study on albino rats by Singh et al., (2008) has shown the effect of the alcoholic extract of Momordica charantia in lowering blood sugar levels feeding for 15 days. Another study on albino rats by Singh, N. and Gupta, (2007) confirmed the anti hyperglycemic effect of $0.25,0.50$ and $0.75 \mathrm{mg} / \mathrm{kg}$ body weight of acetone extract from whole fruit of Momordica charantiain lowering the blood glucose from $13.3 \%$ to $50.0 \%$ after treatment withalloxan.In vitro studies have indicated that Momordica charantia has powerful properties.

Many different substances including antidiabetic properties such as charantin, vicine, and polypeptide-p, and other unspecific bioactive components such as antioxidantsphenolic components may negate the effects of oxidative stress caused by hyperglycaemia (Michael et al., 2006). Metabolic and hypoglycemic effects have been demonstrated in cell culture, animal, and human studies. The oxidative stress has been linked to mechanisms that lead to the dysfunction of both beta and endothelium cells with insulin resistance which can lead to diabetes (Avogaro, 2011).

In conclusion, Momordica charantia has been widely studied for its medicinal properties to treat many diseases. This may be due to the fact that Momordica charantia possesses about 225 different medicinal compounds (Taylor, 2002). All these compounds may act either separately or together to exert their beneficial effects via several mechanisms to control and treat many diseases.

The aqueous extract of Momordica charantia fruit dose of $0.75 \mathrm{mg}$ has an effect on diabetes through reducing the level of glucose in the serum. To date, there is insufficient evidence to investigate the effectiveness of traditional Malaysian vegetables Momordica charantiain modulating blood glucose concentrations.

\section{References}

Englberger, K. 2009. Invasive weeds of Pohnpei: A guide for identification and public awareness. Kolonia, Federated States of Micronesia: Conservation Society of Pohnpei, 29 pp.

Abdollah, M., Zuki, A., Goh, Y., Rezaeizadeh, A. and Noordin, M. 2010. The effects of Momordica charantia on the liver in streptozotocin-induced diabetes in neonatal rats. Afr. J. Biotechnol., 9(31): 5004-5012.

Ahmed, I., Adeghate, E., Sharma, A., Pallot, D. and Singh, J. 1998. Effects of MormodicaCharantia fruit juice on islet morphology in the pancreas of streptozotocin diabetic rats. Diabetes Res. Clin. Pract., 40: 145-151.

Akhtar, N., Khan, B., Majid, A., Khan, S. and Mahmood, T. 2011. Pharmaceutical and biopharmaceutical evaluation of extracts from different plant parts of indigenous origin for their hypoglycemic responses in rabbits. Acta Pol. Pharm., 68(6): 919925.

Avogaro, A. 2011. Postprandial glucose: marker or risk factor, Diabetes Care, 34: 2333-5. 
Bergmeyer, H.U., Gawehn, K. and Grassl, M. 1974. in Methods of Enzymatic Analysis (Bergmeyer, H.U. ed) Volume I, Second Edition, 457-458, Academic Press, Inc., New York, NY.

Bhushan, M., Rao, C., Ojha, S., Vijayakumar, M. and Verma, A. 2010. An analytical review of plants for anti diabetic activity with their phytoconstituent and mechanism of action. IJPSR., 1(1): 29-46. 65.

Chen, Q., Chan, L.L., Li, E.T. 2003. Bitter melon (Momordica charantia) reduces adiposity, lowers serum insulin and normalizes glucose tolerance in rats fed a high fat diet. J. Nutr., 133(4): 1088-93.

Chen, J.C., Liu, W.Q., Lu, L., Qiu, M.H., Zheng, Y.T., Yang, L.M. 2009. Kuguacins $\quad \mathrm{F}-\mathrm{S}, \quad$ cucurbitane triterpenoids from Momordica charantia. Phytochem., 70: 133-140.

Cunnick, J.E., Sakamoto, K., Chapes, S.K., Fortner, G.W. and Takemoto, D.J. 1990. Induction of tumor cytotoxic immune cells using a protein from the bitter melon (Momordica charantia). Cell Immunol., 126: 278-89.

Dans, Villarruz, M., Jimeno, C., Javelosa, M., Chua, J.and Bautista, R. 2007. The effect of Momordica charantia capsule preparation on glycemic control in type 2 diabetes mellitus needs further studies. J. Clin. Epidemiol., 60: 554-9.

Der-Marderosian, A., Beutler, J.A. 2010. Bitter Melon. Review of Natural Products. Facts \& Comparisons, Louis, MO,Wolters Kluwer Health Inc.

Fua, W., Chena, J., Caia, Y., Leia, Y., Chenb, L., Peic, L., Zhoua, D., Lianga, X. and Ruana, J. 2010. Antioxidant, free radical scavenging, antiinflammatory and hepatoprotective potential of the extract from
Parathelypterisnipponica(Franch. et Sav.),Ching. J. Ethnopharmacol., 130: 521-528.

Fuangchana, A., Sonthisombata, P., Seubnukarnb, T., Chanouanc, R., Chotchaisuwatd, P. and Sirigulsatiene, V. 2011. Hypoglycemic effect of bitter melon compared with metformin in newly diagnosed type 2 diabetes patients. J. Ethnopharmacol., 134: 422-428.

Hasan, I. and Khatoon, S. 2012. Effect of Momordica charantia (bitter gourd) tablets in diabetes mellitus: Type 1 and Type 2. Prime Res. Med. (PROM), 2(2): 72-74.

Horax, R., Hettiarachchy, N. and Islam, S., 2005. Total Phenolic Contents and Phenolic Acid Constituents in 4 Varieties of Bitter Melons (Momordica charantia) andAntioxidant Activities of their Extracts, J. Food Sci., 70.

I3N-Brasil. 2014. Base de dados nacional de espéciesexóticasinvasora (National database of exotic invasive species). Florianópolis - SC, Brazil: I3N Brasil, InstitutoHórus de Desenvolvimento e ConservaçãoAmbiental. http://i3n.institutohorus.org.br

Joseph, B. and Jini, D. 2011. A medicinal potency of Capparis decidua - A harsh terrain plant. Res. J. Phytochem., 5(1): $1-13$.

Kar, A., Choudhary, B.K., Bandyopadhyay, N.G. 2003. Comparative evaluation of hypoglycaemic activity of some Indian medicinal plants in alloxan diabetic rats. J. Ethnopharmacol., 84(1): 105-8.

Kubola, J. and Siriamornpun, S. 2008. Phenolic contents and antioxidant activities of bitter gourd (Momordica charantia L.) leaf, stem and fruit fraction extracts in vitro .Food Chem., 110: 881-890. 
Lee, S., Eom, S., Kim, Y., Park, N. and Park, S. 2009. Cucurbitane-type triterpenoids in Momordica charantiaLinn. Medicinal Plants Res., 3: 1264-1269.

Lee-Huang, S., Huang, P.L., Chen, H.C., Bourinbaiar, A., Huang, H.I. and Kung, H.F. 1995. Anti-HIV and antitumor activities of recombinant MAP30 from bitter melon.Gene, 161, 151-6.

Lim, S., Jimeno, C., Razon-Gonzales, E. and Velasquez, M.(2010. The study the effect of Momordica charantia tablets on glucose and insulin levels during the postprandial state among patients with type 2 diabetes mellitus, Philipp. J. Intern. Med., 48:19-25.

Lim, T.K. 2013. Edible medicinal and nonmedicinal plants, Dordrecht: springer, 331-332, ISBN 9789400717640.

Matsuda, H., Li, Y., Murakami, T., Matsumura, N., Yamahara, J. and Yoshikawa, M. 1998. Antidiabetic principles of natural medicines. III. Structure-related inhibitory activity and action mode of oleanolic acid glycosides on hypoglycemic activity. Chem. Pharm. Bull., (Tokyo), 46: 1399-403.

Michael, B., Krawinkel, G., and Keding, B. 2006. Bitter Gourd (Momordica charantia. a Dietary Approach to Hyperglycemia, International Life Sciences Institute, 331-337.

Mohammady, I., Elattar, S., Mohammed, S. and Ewais, M. 2012. An evaluation of anti-diabetic and anti-lipidemic properties of Momordica charantia (Bitter Melon) fruit extract in experimentally induced diabetes. Life Sci J., 9(2): 363-374.

Mohd, F., Bachok, B.,,Barakatun,N. ;Mohd, Y. Amin, I. and Azizah, A. 2014. Effectiveness of traditional Malaysian vegetables (ulam) in modulating blood glucose levels, Asia Pac. J. Clin. Nutr., 23(3): 369-376.

Nagasawa, H., Watanabe, K. and Inatomi, H. 2002. Effects of bitter melon (Momordica charantia 1.) or ginger rhizome (Zingiberoffifinalerosc) on spontaneous mammary tumorigenesis in SHN mice. Am. J. Chin. Med., 30: 195-205.

Nerurkar, P., Lee, Y.,, and Nerurkar, V. 2010. Momordica charantia (bitter melon) inhibits primary human adipocyte differentiation by modulating adipogenic genes. $B M C$ Complement Altern Med., 10: 34.

Ooi, C.P., Yassin, Z; Hamid, T.A. 2012. Momordica charantia for type 2 diabetes mellitus. The Cochrane Library 8: CD007845. doi:10.1002/14651858.CD007845.pub 3. PMID 22895968

Ragasa, C., Alimboyoguen, A. and Shen, C. 2011. Del Fierro RS, Raga DD. Hypoglycemic effects of tea extracts and sterols from Momordica charantia. J. Nat. Remedies, 11: 4453.

SAS. 2012. Statistical Analysis System, User's Guide. Statistical. Version 9.1th ed. SAS. Inst. Inc. Cary. N.C. USA.

Shibib, B., Khan, L. and Rahman, R. 1993. Hypoglycaemic activity enzymes glucose-6-phosphatase and fructose1,6-bisphosphatase and elevation of both liver and red-cell shunt enzyme glucose-6-phosphate dehydrogenase. Biochem., 292: 267-270.

Singh, J., Cumming, E., Manoharan, G., Kalasz, H. and Adeghate, E. 2011. Medicinal chemistry of the antidiabetic effects of Momordica charantia: active constituents and modes of actions. Open Med. Chem. J., 5: 70-77. 
Singh, L.W. 2011. Traditional medicinal plants of Manipur as anti-diabetics. $J$. Med. Plants Res., 5(5): 677-687.

Singh, N. and Gupta, M. 2007. Regeneration of $\beta$ cells in islets of langerhans of pancreas of alloxan diabetic rats by acetone extract of Momordica charantia (Linn.) (bitter gourd) fruits. Indian J. Exp. Biol., 45: 1055-1062.

Singh, N., Gupta, M. and Sirohi, P. 2008. Effects of alcoholic extract of Momordica charantia (Linn.) whole fruit powder on the pancreatic islets of alloxan diabetic albino rats. $J$. Environ. Biol., 29(1): 101-106.

Stevens, P.F. 2012. Angiosperm Phylogeny Website.

http://www.mobot.org/MOBOT/resear $\mathrm{ch} /$ APweb.

Taylor, L. 2002. Herbal secrets of the rainforest. In: Texas A, editor. Bitter melon (Momordica charantia) 2nd ed. USA: Sage Press; pp. 1-100.

Wehash, F., Abpo-Ghanema, I. and Saleh, R. 2012. Some physiological effects of
Momordica charantia and Trigonellafoenum-graecum extracts in diabetic rats as compared with cidophage ${ }^{\circledR}$ World Acad. Sci. Engi. Technol., 64: 1206-1214.

Welihinda, J., Karunanayake, E., Sheriff, M. and Jayasinghe, K. 1986. Effect of Mormodica charantia on the glucose tolerance in maturity onset diabetes. $J$. Ethnopharmacol., 17: 277-282.

Yasuda, S., Yogosawa, S., Izutani, Y., Nakamura, Y., Watanabe, H. and Sakai, T. 2009. Cucurbitacin B induces G(2) arrest and apoptosis via a reactive oxygen speciesdependent mechanism in human colon adenocarcinoma SW480 cells. Mol. Nutr. Food Res.

Yuan, X.Q., Gu, X.H., Tang, J. and Wasswa, J. 2008. Hypoglycemic effect of semipurified peptides from Momordica charantia 1. var. abbreviata ser. in alloxan induced diabetic micE. J. Food Biochem., 32: 107-121.

\section{How to cite this article:}

Maha Hameed A. Al-Bahrani. 2016. The Role of Momordica charantia in Reducing the Level of Glucose in Mice. Int.J.Curr.Microbiol.App.Sci. 5(8): 470-478.

doi: http://dx.doi.org/10.20546/ijcmas.2016.508.050 